\title{
New age advice: ticket to happiness?
}

\author{
Maarten C. Berg
}

Published online: 28 February 2007

(C) Springer Science+Business Media B.V. 2007

\begin{abstract}
The 'New Age' movement emerged in the second half of the 20th century and New Age ideas became the vogue in the Western world. New Age is much concerned with personal quality of life and offers both a philosophy of life and various therapeutic practices, presumed to raise happiness. This paper first describes the main recommendations to be found in New Age books. Next it considers the probable effects on happiness of these, by examining both the theoretical plausibility and the empirical conditions of happiness. This paper concludes that several recommendations are likely to produce beneficial consequences. It is argued, however, that the advice will not fit everybody equally well and that some New Age practices may reduce happiness, e.g., practices that undermine a realistic outlook on reality.
\end{abstract}

Keywords New Age $\cdot$ Spirituality $\cdot$ Happiness $\cdot$ Effect study $\cdot$ Subjective well-being

\section{Introduction}

The term 'New Age' was first used by a spiritual movement that emerged in developed nations in the 1950s. It referred to the astrological notion of the 'Age of Aquarius' which is supposed to be characterized by harmony, cooperation, and spiritual wisdom in contrast to the preceding 'Age of Pisces' that is believed to be violent, selfish, and materialistic. The term New Age, therefore, implied drastic societal changes. Currently, the term is also used for a contemporary philosophy of life that has developed some features of a religion. In this paper, we use the term in the latter meaning. We refer to New Age as a set of ideas that are part of a loosely organized spiritual movement.

The New Age philosophy is to a great extent about personal quality of life. Its main 'product' is advice for self-improvement and greater happiness. Although

M. C. Berg (ه)

Department of Sociology, Erasmus University Rotterdam,

P.O. Box 1738, 3000 Rotterdam, The Netherlands

e-mail: berg@fsw.eur.nl 
originally the New Age movement was concerned with social reform, it has developed in a more individualistic direction, and came to focus on therapeutic practices. In this paper, the effects of New Age advice on happiness (in the sense of general 'life-satisfaction') are examined.

\section{Method}

\subsection{Approach}

A qualitative content-analysis was used to select ten main recommendations embodying New Age philosophy. As a quantitave approach is often problematic in terms of capturing the precise meanings of advice, close reading was preferred. Although such a selection is, to some extent, somewhat arbitrary, one can safely claim that the ten recommendations below represent New Age philosophy quite accurately.

To illustrate the advice, quotes from famous New Age books were used. Some of the quotes were collected from Tom Butler-Bowdon's 50 spiritual classics, a book that gives a broad and representive overview of New Age's best-known authors and titles. Some quotes are from other authors, not mentioned in 50 spiritual classics. These authors were selected for their visibility in (Dutch) libraries and bookstores today.

The advice is judged in terms of its probable effects on happiness. These probable effects are claimed on the basis of relevant happiness-literature. As a complete overview of all operationalizations and measurements of independent variables would be too detailed for the purpose of this article, I would like to refer to the original sources.

\subsection{Concept of happiness}

The term 'happiness' in New Age terminology is an umbrella-concept, referring to all good: from enjoyment to wisdom and from love to peace of mind. In this article, 'happiness' will be used in a narrower sense, as an equivalent for 'life-satisfaction.' The question is whether following New Age advice is likely to add to the 'overall enjoyment of one's life-as a whole' (cf. Veenhoven, 1984, pp22-25). This definition of happiness is also in line with Diener's (1984) concept of 'subjective well-being.'

\subsection{Outline of this paper}

The paper consists of four sections: (1) an outline of the New Age philosophy, (2) a summary of the main recommendations for improving one's life, (3) an examination of the potential effects on happiness, among which possible adverse effects, and (4) a discussion of actual effects.

\section{New age philosophy}

New Age is not a philosophy in the sense of a rational system of thought. It is rather a set of more or less related beliefs and practices and could also be depicted as a 
'pseudo religion.' Although its supporters do not worship a God as do traditional monotheistic religions, they typically assume that there is 'something more out there' and that there is some sacred truth in this universe that one cannot grasp rationally. New Age differs from established religions by its absence of temples, priests, and hierarchal organization. Still, there is some institutionalization. New Age philosophy is conveyed through a network of websites, magazines, books, and courses. The movement is organized as a niche-market. As a result, New Age cannot be described on the basis of a common statement of principles. Yet, it can be typified by the following characteristics.

\subsection{Eclectic}

New Age is profoundly eclectic. It combines elements of many different religions, philosophies, practices, and traditions. Topics as different as dreams, palmistry, meditation, UFO's, telepathy, yoga, reincarnation, homeopathy, shamanism, and aura's can all be categorized under New Age. Moreover, followers differ greatly in which elements they incorporate in their lives. New Age assumes that all religions are mere manifestations of the same cosmic truth (e.g., Blavatsky, 1950) and this makes New Age tolerant toward different religions, philosophies, experiences, and lifestyles. At the same time, however, New Age is relativistic and postmodern and rejects the exclusive validity of any particular religious authority.

\subsection{Spiritual}

The existence of a spiritual reality in addition to the physical world is a fundamental assumption. Many participants describe this spiritual dimension in terms of omnipresent cosmic energy, love, and wisdom. Science is just one source of knowledge. That does not mean that scientific knowledge is inferior. Actually, New Age authors often aim to combine the traditional esoteric-religious assumptions with a modern, rational, and critical worldview (Aupers \& Van Otterloo, 2000, pp27-34). Authors such as Zukav and Capra have a scientific background. Other authors tend to lend a scientific style to their work by incorporating physics, mainstream psychology, and (famous) philosophers. Nevertheless, New Age is mainly about spirituality. Becker, de Hart, and Mens (1997) point out that (Dutch) New Age participants had a religious upbringing more often than non-participants. Equally relevant is their observation that the rise of New Age in the Netherlands goes together with secularization. This seems to indicate that the decline of Christian religion has created a need for spiritual compensation.

\subsection{Experiential}

Personal experience is more important in New Age than in many other philosophies of life. New Age originated in Western esoteric traditions (Hanegraaff, 1996). The term 'esoteria' literally refers to one's inner experience. A basic assumption of the esoteric tradition is that (religious) knowledge is exclusively obtained through personal experience and not through external authorities and writings. The reason for this is that in the New Age philosophy God is not separate from us, but a divine source within. External guidelines and authority are, therefore, replaced by internal cues. As New Age is sometimes called a solipsistic (self-centered) religion, it is no 
surprise that it flourishes in an individualistic society. Although New Age was occupied with social criticism during the 1950, 1960, and 1970s, it is currently more psychological and individualistic in nature (Aupers \& Van Otterloo, 2000, pp68-70).

\subsection{Holistic}

A key belief is that different elements in the universe are connected in some way and part of a whole. The body and mind, for example, are one in contrast to the dualism proposed by Descartes. New Age sees also unity between God and nature, the concept of pantheism. A third example of holism is the idea that mankind is essentially divine (deification) and that the distinction between holy (God) and unholy is a product of our imagination. The idea of holism has great (practical) implications. A doctor, for example, should not rely on the reductionistic approach of focusing on particular symptoms, but should also take into account the client's general health, well-being, spirituality, background, and relationships.

\subsection{Therapeutic}

Not all New Age followers are attracted by the philosophy in the first place, but rather seek ways to improve the quality of their lives. Aupers and Van Otterloo (2000, p131) speak of a therapeutic motivation, and point out that New Age deals with emotional and physical issues rather than with morality and truth. New Age teachers communicate their advice through books, new age shops, centers, courses, and Internet newsgroups. Although the practices are related to the philosophical assumptions discussed above, they exist relatively independently of New Age theory.

\subsection{Counter current}

In a sociological perspective, New Age can be characterized as a societal 'counter current.' In many ways it goes against dominant conviction, it calls for spirituality in a climate where rationality prevails and sees a sacred unity in a world that is ever more understood in its components. New Age expresses values that are not expressed in the dominant culture: non-materialism, intuitive thinking, and personal experience. In this view, New Age is a product of modernization, in spite of its glorification of traditional wisdom.

\section{New age advice}

What does New Age advise concretely? What views on life are advanced? What practices recommended? There is no easy answer to these questions, since the movement lacks an authorized system of beliefs and rules. Hence there is much diversity between different authors and writings do not always match practices. Still we can discern the following ten recommendations that often appear in the literature.

\subsection{Become spiritual}

Spirituality refers to devotion to metaphysical matters, as opposed to worldly things. Almost every New Age author agrees that one should incorporate this spiritual 
dimension in one's life. Not only can people obtain a more complete outlook on life, but also they can be more fulfilled.

It is typical of modern life that nature is set up to be random and chaotic. This is far from true (...). To bring God back, we have to follow new, even strange responses wherever they lead us. As one spiritual teacher wisely put it, "The material world is infinite, but it is a boring infinity. The really interesting infinity lies beyond (Chopra, 2001).",

\subsection{Be authentic}

Although the authentic (true) self is a loving and flawless entity, this divine core is not always manifest in everyday behavior. Life's quest, therefore, is to close the gap between one's true (perfect) self and how one actually behaves, thinks, and experiences. We must realize that career, possessions, hobbies, habits, and life-circumstances should be mere manifestations of a deeper spiritual truth. As Dass (1971) puts it (cf. Butler-Bowdon, 2005, p72).

I had an apartment in Cambridge that was filled with antiques and I gave very charming dinner parties. I had a Mercedes-Benz and a Triumph 500cc motorcycle and a Cessna 172 airplane and an MG sportscar and a sailboat and a bycicle. I vacationed in the Caribbean where I did scuba-diving. I was living the way a succesful bachelor professor is supposed to live in the American world of 'he who makes it'. I wasn't a genuine scholar, but I had gone through the whole academic trip. I had gotten my PhD; I was writing books...But what all this boils down to is that I was really a very good game player.

\subsection{Know yourself}

This advice resembles the previous, but is more psychological and less metaphysical than the advice to be authentic. It is thought to be important to be aware of your feelings, motives, and behavior and to understand how you influence your own life. You cannot heal what you do not know and acknowledge. Krishnamurti (1995) on self-knowledge:

The transformation of the world is brought about by the transformation of oneself, because the self is the product and a part of the total process of human existence. To transform oneself, self-knowledge is essential; without knowing what you are, there is no basis for right thought, and without knowing yourself there cannot be transformation. One must know oneself as one is, not as one wishes to be, which is merely an ideal and therefore fictitious, unreal.

\subsection{Connect to the world}

New Age thinks of love as the fundamental nature of mankind. It is both the purpose and the essence of life. It must be noted that the advice to connect is not restricted to family, friends or potential lovers. It is not even restricted to concrete human interactions. Love is a mainly spiritual connection with all elements in the cosmos. Since love (by New Age definition) is spiritual, unconditional, and non-exclusive, it 
is at the same time somewhat impersonal. Walsch (1997) says the following about love in Conversations with God, book two:

It is time for the world to stop kidding itself, to wake up, to realize that the only problem of humanity is lack of love. Love breeds tolerance and tolerance breeds peace. Intolerance produces war and looks indifferently upon intolerable conditions. Love cannot be indifferent. It does not know how. The fastest way to get a place of love and concern is to see all human kind as your family. The fastest way to see all human kind as your family is to stop separating yourself.

Connection in the New Age sense refers to a sense of unity that is not necessarily accompanied by social activity. One should help others because others are fabricated from the same divine energy and therefore a part of the self. One should also look after oneself and not allow abuse, since the self is a precious part of the whole.

\subsection{Meditate}

The meditative state of mind is recommended for two reasons. First, meditation could be a key to lower stress and to control emotions. In that sense, there are parallels between New Age and the stoic philosophical tradition.

No matter which path you follow for meditation, the first and foremost task is to try to make the mind calm and quiet. If the mind is constantly roaming, if it is all the time a victim of merciless thoughts, then you will make no progress whatsoever. The mind has to be made calm and quiet so that when the light descends from above, you can be fully conscious of it. In your conscious observation and conscious acceptance of light, you will enter into a profound meditation and see the purification, transformation, and illumination of your life (Chinmoy, 1979).

Second, meditation is a tool for mindful living, for experiencing life fully. Reducing one's thoughts ought to lead to a more direct experience of everyday reality in line with Sartre's existential philosophy. According to New Age followers, most people are too busy to be mindful. By worrying or fantazising about the future or thinking about the past, people miss out on life itself (cf. Butler-Bowdon, 2005, p192).

Don't drink your tea like someone who gulps down a cup of coffee during a workbreak. Drink your tea slowly and reverently, as if it is the axis on which the whole earth revolves-slowly, evenly, without rushing toward the future. Live the actual moment. Only this actual moment is life (Nhat Hanh, 1975).

\subsection{Think positively}

Where many traditional religions emphasize humbleness and shame, New Age shares with pop-psychology and the self-help literature a focus on optimism and selfesteem. The following quote is by Dyer (1997), who is both a (pop-) psychologist and a New Age writer.

You see in great detail what it is that you want, and repeatedly affirm this picture with faith in the absolute power that is in all things, including yourself. 
You can picture yourself healthy, your business thriving, your sales quotas being met, your relationships healing, your house selling, finance coming your way or anything you desire. The key is to repeat these mental pictures until the truth of what you are affirming resonates within you without an ounce of doubt.

\subsection{Take control}

New Age is inspired by Eastern influences and its focus on acceptance and on the "natural flow" of the world. Moreover, concepts such as karma, collective consciousness, and energy spots are characteristic of a deterministic worldview with limited influence for the individual soul. Still, most New Age authors stress concious choice. Given the influences one is subjected to, one can create and manifest the life one chooses through one's words, deeds, thoughts, and states of mind. The following quote is by Carlos Castañeda (1972) (cf. Butler-Bowdon, 2005, p48):

My interest has been to convince you that you must assume responsibility for being here, in this marvelous world, in this marvelous desert, in this marvelous time. I wanted to convince you that you must learn to make every act count, since you are going to be here for only a short while; in fact, too short for witnessing all the marvels of it.

\subsection{Live healthily}

Although mental and spiritual growth are central in New Age philosophy, much of its practical advice concerns physical health. This is no contradiction, since the holistic approach implies a "mens sana in corpore sano" (a healthy mind in a healthy body). One can become healthier by doing mental and emotional work, but the reverse is also true. Good care of the body is a manifestation of self-respect. The simplest way to stay healthy is to listen to the signals of the body. To eat when you are hungry and to stop when you are full. The focus is on organic (often vegetarian), non-chemical food, and on natural, gentle exercise. Hay (1984) believes that sickness results from certain states of mind, especially the inability to forgive.

Whatever we send out mentally or verbally will come back to us in like form (....). If we are willing to do the mental work, almost anything can be healed.

\subsection{Live simply}

Although some New Age authors claim that spirituality and consumption are not necessarily incompatible, the majority focus on inner richness, simplicity, and nonmaterialistic values. This makes sense given New Age's central proposition that a spiritual reality exists beyond the physical world.

When we appreciate how much we have, we feel the urge to pare down, get back to basics, and learn what is essential for happiness. We long to realize what's really important. Is it important for you to work overtime to buy that new dining room or to attend Little League games? Perhaps you could refinish the table and chairs you now have and add some colorful cushions. These 
choices are part of simplifying our lives. Welcome them. They are part of the authentic journey (Ban Breathnach, 1995).

\subsection{Follow your gut feelings}

Intuition is considered to be the most reliable source of information. When listening to one's true self and being open to inner signals, one taps into authentic, spiritual knowledge. The importance of intuition is a central element in Redfield's The Celestine Vision (1997):

Throughout history, humans have always talked about the experience of gut feelings or hunches that have directed us at various times in the decisions we make in life. Only the mechanistic worldview discounted such experiences as illusion or hallucination or reduced them to mere social cues. Even in the face of this cultural disapproval, most of us have continued to use such feelings halfconsciously; we just didn't discuss them much. Only in recent decades has the power of intuition once again become more openly used and talked about in the West.

New Age authors stress that what is generally believed is not necessarily true; and this fits our interpretation of New Age as a counter movement.

\section{Probable effects on happiness}

Will these recommendations make life more rewarding? Armchair theorizing cannot answer that question, only empirical research can. As yet there is little research on the happiness of New Age devotees and certainly no controlled follow-up studies on the effect of New Age practices on happiness. Still, there are several research findings that are at least indicative for the effectiveness of some of the recommendations mentioned above. In this section, I will review that empirical evidence. Note that these data are typically from general population samples and that the findings may not apply to the specific clientele of New Age. Yet New Age advice is typically presented as good for anybody, so a check of that claim is justified.

\subsection{Spirituality and happiness}

All New Age advisors recommend to go spiritual. Will that make life more satisfying? We know from many studies that happiness is greater for the religious, and this information is relevant because we noted in Sect. 1 that New Age can be considered a pseudo-religion. Therefore, some of the beneficial effects of traditional religion might apply to New Age spirituality as well. In a meta-analysis of 28 American studies Witter, Okun, Haring-Hidore, and Stock (1985) found a moderate positive correlation between religiousness and happiness. This does not necessarily mean, however, that a religious life causes greater happiness. It could also be the case that religion attracts happy people. Chiriboga (1982) investigated the matter longitudinally and found that church attendance predicted happiness 15 years later in elderly individuals. As spirituality and religiousness are different concepts, it may seem strange to refer to this kind of evidence. 
Social support seems to be an important explanation for the 'religion effect.' Moberg and Taves (1965) found that the benefits of the church are greatest for those who are single, old, retired or in poor health. Another argument for the social support hypothesis comes from Witter et al. (1985). Although they only found moderate positive correlations between religion and happiness, they found a stronger effect for church attendance. Kaldor (1994) found that $70 \%$ of all church attenders in Australia had close friends in the church community. This confound between religiosity and social support seems to indicate that the solipsistic New Age philosophy is less advantageous.

There is more to religion than social support, though. Those who have had religious experiences are happier: Greeley (1975) found a correlation of 0.60 between reporting having been "bathed in light" and positive affect. Halman, Heunks, Moor, and Zanders (1987) found that after controlling for social contacts and demographic factors such as age, class, and education, a significant contribution of religion to happiness remained. Pollner (1989) found that reported "closeness to God" correlated 0.16 with happiness and satisfaction when church attendance had been controlled. These findings are relevant for an evaluation of New Age. Moreover, the idea of purpose might offer something extra in addition to the somewhat cold rationalism or agnosticism.

Two other explanations of the positive effect of religion overlap with other advice and will be discussed in more detail below. First, many religions (and New Age) advocate a moderate, healthy lifestyle. Second, religious beliefs might give people existential security and, as a result, enhance perceived controllability of life (Gall, 2000). It seems, overall, that a spiritual outlook on life can be beneficial.

\subsection{Authenticity and happiness}

As authenticity in the New Age terminology often refers to a divine inner source that most people are not even consciously aware of, the concept cannot be measured. This makes the relation between authenticity and happiness impossible to investigate. At most, it would be possible to study the effects of 'striving for this kind of authenticity.' Such a study, however, had not yet been conducted. Some New Age authors have a more down to earth view on authenticity and are in line with the work of Seligman (2002). According to Seligman, people derive 'authentic happiness' from activities that fit their particular strengths and personalities. Seligman relies heavily on the work on flow (Csikszentmihalyi, 1990). According to Csikszentmihalyi, people can experience a certain state of mind ('flow') that is characterized by total concentration and involvement with their current activities. Research shows that flow is connected to subjective well being (Csikszentmihalyi, 1975, 1990). When one thinks of authenticity as the awareness of one's flow-generating activities and the ability to incorporate them into one's life, it seems that authenticity and happiness are positively correlated.

\subsection{Self-knowledge and happiness}

Knowing oneself is important in New Age and many of its books and trainings are meant to get in touch with one's thoughts and feelings. This fits with common practice in psycho-therapy, many therapists seeing self-insight as an important aspect of mental health and hence as a precondition for happiness. The psychoanalytic 
tradition, with Freud and Jung as its most famous exponents, is based on the idea that people are governed by unconscious needs and conflicts. As long as people are unaware of what causes their problems, it is impossible for them to attain psychological health. The goal of psychoanalysis, then, is to bring these unconscious forces to the surface (Freud, 1969). Cognitive therapy also stresses gaining self-insight. Negative cognitions need to be identified before they can be changed (e.g., Beck, 1967). From a sociological view it argued that self-insight is especially important in modern, multiple-choice society, since making the right choices requires that one knows what one wants and how things really feel (Veenhoven, 1999). Dunning, Heath, and Suls (2004) state that a lack of self-insight might even be dangerous. When people underestimate their susceptibility to health risks, overestimate their mastery of educational knowledge or are overconfident when making crucial business-decisions, the consequences could be immense.

Yet self-insight can also be detrimental to happiness. An intriguing finding is that depressive people seem to miss the ability to deceive themselves. Alloy and Abramson (1979) showed that they have a more realistic outlook than "normal" people. Taylor and Brown (1988) have suggested that mood-enhancing distortions promote good mental health. Too much self-insight, then seems undesirable, but the positive outlook on the self by New Age advocates indicates that this risk is limited.

\subsection{Connectivity and happiness}

As we have seen New Age recommends a stance of openness to the world, not actual involvement with people and organization, but rather the cultivation of a sense of connection with the universe. Is that a sure ticket for a happier life? The available research is about real-life involvement. One of the findings is that intimate involvement in marriage and friendships makes life more satisfying. In this case, there is evidence of causal effects. People get happier when they find a spouse and get less happy following widowhood or divorce (Nock, 1981; Erbes \& Cunneen Henderson, 1985). Weiss, Buchanan, Altstatt, and Lombardo (1971) gave student participants the opportunity to help other students. They conclude that altruism is rewarding. Piliavin and Callero (1991) found that blood donation is beneficial. Voluntary work enhances mood (Argyle, 1996) and experiments in game-theory prove that behaving well (playing fairly) leads to pleasant experiences (as shown by MRI-scans). There was no such reaction when the game was against a computer (Rilling et al., 2002). Socio-biologists would argue that the concern for other people's interest is genetically inherited. Data about the effect of attitudinal connectivity and happiness are less abundant and do not inform us about cause and effect. We know, however, that trusting people are relatively happy (Headey, 1981) and that the same holds for empathic people (Headey, Kelley, \& Wearing, 1993). The data suggest that the focus on connectivity is good for happiness, but empirical research is needed to determine how New Age works out in practice.

\subsection{Meditation and happiness}

Meditation and related mindfulness techniques are commonly recommended for achieving inner peace. These practices are likely to reduce stress, at least for the moment, but do they also raise satisfaction with life? There are empirical indications of several beneficial effects. Meditation has also proved to be effective in improving 
self-esteem (Alexander, Rainforth, \& Gelderloos, 1991). Athletes use concentration techniques that resemble meditation to get maximum performance (Cox, Liu, \& Qiu, 1996). It is not farfetched to assume that this kind of concentration could also be used in other domains than sports. Some people claim that meditation should not be restricted to meditation sessions. Conscious living can be applied to life as a whole. The term "mindfulness" is often used in the literature, an open or receptive awareness of and attention to what is taking place in the present moment, and this goes together with subjective well being (Brown \& Ryan, 2003).

From a negative perspective, one could wonder whether meditation might foster introversion, which appears to affect happiness negatively (Heady \& Wearing, 1992). Moreover, intensive meditation might prevent people from taking part in daily life and this could have negative implications beyond introversion itself (e.g., Myers \& Diener, 1995). By lack of good experimental research, this issue remains undecided for the time being.

\subsection{Positive thinking and happiness}

As we have seen, New Age advises to look at the bright sides of life and much of its trainings aim at cultivating that stand. Like in the case of self-insight, this fits the common view in psycho-therapy, e.g., Rational Emotive Therapy (RET) that aims to redress irrational, negative thoughts, and beliefs (Ellis \& Grieger, 1977). Yet not all pessimistic thoughts are irrational, remember the case of "depressive realism" mentioned above, and unfounded optimism can lead to failure and disillusion (Norem \& Chang, 2002). Hence we must assess empirically how the effects balance in practice. There is a lot of research on the matter that typically suggests that the positive effects prevail. Optimists tend to be happier than pessimists (Matlin \& Gawron, 1979; Abdel-Khalek, 2003). The same holds for those who feel secure about their future (Cummins, Eckersley, Lo, \& Okerstrom, 2003). Since these correlations do not prove causal effects of positive thinking on happiness, some longitudinal studies must be mentioned. Optimism predicts happiness 2 years later (Wessman \& Ricks, 1966). Earlier positive thinking predicts happiness later on (Goodhart, 1985). The bright outlook on life that New Age advocates is probably beneficial for happiness.

\subsection{Control and happiness}

A common element in New Age advice is to take control over one's life and accept personal responsibility. The argument is that once you accept responsibility for what your life is like, it is easier to change it in the way you want. This position is common currency in psychology. Mirowsky and Ross (1990) showed that the picture is somewhat complicated, however. An "internal locus of control" is beneficial in favorable and privileged conditions, but has detrimental effects when outcomes can be little regulated. An illusory perception of control is maladaptive and can even be linked to depression. Again the data must tell which effect dominates for the average citizen of this time. Most research findings shows distinct positive effects of an internal locus of control (e.g., Larson, 1989; Ryff \& Keyes, 1995; Timmermans, 1997). Moreover, an internal locus of control predicts happiness in later years (e.g., Palmore, 1981). The advice to take life into one's hands seems to be productive. 


\subsection{Health and happiness}

A healthy lifestyle is also commonly advised and there is good evidence that this does affect physical health and longevity. But does that make life more satisfying? There may be costs in healthy living and it has been claimed that the loss involved in renouncing the pleasures of smoking and drinking may not balance the lousy years gained. What do the available data tell? Several studies show strong correlations between physical health and happiness (e.g., Okun \& George, 1984; Brief, Butcher, George, \& Link, 1993). According to Feist et al. (1995) the relation goes in both directions, implying that a healthy life contributes to happiness. But the other direction of causation is equally relevant. As happiness leads to better health, the effect strengthens itself. The effects of happiness on health are comparable to not smoking (Veenhoven, 2005a, b).

Still, the effect of health on happiness is not as strong as one might expect. An intriguing and consistent finding, moreover, is that people generally adapt remarkably well to very serious diseases and disabilities (Brickman, Coates, \& JanoffBulman, 1978). A somewhat related finding is that self-reports measures ("subjective health") show a stronger correlation with happiness than objective measures of health (e.g., Suchman, Phillips, \& Streib, 1958). This suggests that the appraisal of one's situation is more important than the situation itself.

A final point is that health is not only important in terms of its contribution to a happier life, but also in terms of a longer life. Since most people are happy, an extension of life will add to net happiness, even if happiness were to decrease a little at old age. The concept "happy life years" (Veenhoven, 1996) integrates happiness and duration of life, and is possibly a better dependent variable than happiness itself. The New Age advice to live healthy is solid.

\subsection{Lifestyle and happiness}

New Age advocates a simple life, and advises against conspicuous consumption and sensation seeking. There are certainly advantages to such a constricted life-style, but it could also be boring. How do these effects balance on happiness?

First, the theory that money is negatively correlated with happiness is incorrect. Between-country studies show a curvilinear relation (Diener, Sandvik, Seidlitz, \& Diener, 1993). For poor countries, additional national income contributes to national happiness. Rich countries, however, are probably above the level at which income affects happiness. Although this supports the idea that there is a limit to what wealth can offer, there are no signs that money might have detrimental effects. Withincountry studies also show a positive relation between income and happiness, although (again) this relation is much stronger in poor countries (e.g., Veenhoven, 1994). Materialistic people are on average less happy (Belk, 1984). Possibly, a materialtic attitude itself is undermining our well being. Possibly, materialistic people fail to give priority to relationships and leisure. Having possessions beyond the basic necessities, though, does not necessarily make people materialistic. Happy people, therefore, have enough money to buy them their material necessities and enough free time for important relations and meaningful activities, without developing a materialistic attitude.

Veenhoven (2001) examined the effects on happiness of hedonistic behaviors and attitudes (e.g., alcohol consumption, sexual activity, smoking, and attitude to leisure) 
both at an individual and at a societal level. He concluded that a (somewhat) hedonistic lifestyle seems to contribute to a happy life, although relations might be spurious and additional happiness might be balanced by a loss in physical health. The conclusion must be that the New Age focus on the simple life is unnecessary, but the warning against the disadvantages is warranted.

\subsection{Intuition and happiness}

A main theme in New Age advice is that one should listen to one's feelings and not trust the ratio too much. Again there are arguments for and against this position and we need empirical research to establish how this recommendation should be evaluated. Yet in this case we are empty handed, since there is no good research on the matter. So for the time being this matter remains undecided.

\section{Discussion}

It seems that most of the New Age advice could work out positively for most people. In seven of ten cases discussed above, there is at least indirect evidence for positive effects, while there are no empirical indications for negative net-effects. Yet the conclusion that New Age advice could further happiness is no guarantee that it actually will. One reason is that the advice may not be suited for New Age's specific clientele. A second reason can be that the (good) advice may be applied inappropriately by this clientele. A third caveat concerns the concrete practices through which New Age advice is communicated.

\subsection{Suitable for the clientele?}

The conclusions of the foregoing section were based on research in general population samples. Advice that may be good for one (group of) individual(s), may not be good for another, though. Stated differently, the value of advice is a function of its content and the characteristics (personality, specific circumstances, and life history) of its targets. There are good reasons to assume that the average customer of New Age advice does not match the general population in important respects. As a result, the conclusions do not necessarily apply to New Agers.

\subsection{Properly applied?}

A second point of nuance concerns the possible (unconscious or semi-conscious) misinterpretation of advice by those who receive it. The advice itself might be good, but target decoding might transform advantageous into disadvantageous. New Age followers may only incorporate those elements of New Age pop-psychology in their lives that appeal to them, and are reassured in doing so by the advice to trust their own gut-feelings. New Age psychology itself, of course, is at best a simplified extract of its scientific source. People might use this over-simplification of New Age advice to minimize and sustain their own dysfunctional behavior.

The 'advice to connect' illustrates these points. As was discussed earlier, the New Age concepts of love and relating are somewhat different from their usual meanings. 
Since everyone is the object of one's love (including the self), no one is in particular. An impersonal, universal equivalent of love might not be as beneficial as having concrete social ties. Some people might even use the New Age conceptualization of love as a coping-strategy for dealing with relational disappointment: "He may not love me, but at least I love myself." This form of 'self-illusion' is not necessarily negative and probably even adaptive, unless it keeps people inactive regarding looking for potential friends and partners in everyday life. Although New Age involvement might bring new friends with a similar outlook on life, extreme New Age participation might also alienate people from their friends and loved-ones. Another relevant example is the advice to distrust experts. Although there is a positive relation between individuality and happiness, it is obvious that it is not always wise to go your own way. In some cases people know best themselves, where in other cases experts (doctors, counselors) or even friends have a more accurate outlook on the situation at hand.

\subsection{Could New Age practices undermine potential benefits?}

Although some New Age courses might be aimed to foster optimism and some books to improve self-knowledge, it is not always obvious that these practices have the hoped-for effects. Even if we accept, for example, optimism and self-knowledge as preconditions for happiness, we still need to investigate whether concrete practices (astrology, rebirthing, etc.) are beneficial in that respect.

\subsection{Future research}

The conclusion must be that New Age advice can be advantageous but more research on target characteristics and the specific conditions under which the discussed advice is actually effective is desirable. Another possible research extension concerns the direct assessment of New Agers' happiness. One could measure changes in happiness scores during participation in New Age courses. This would be comparable to effect-studies on clinical (or medical) intervention. Despite the problems with this type of research, concerning long-term effects and (threats to) the internal validity, this would be an intriguing way to go.

\section{Conclusion}

The New Age movement is a pseudo-religion that focuses on the quality of life in the here and now. The ten main recommendations for a happy life are: (1) Become spiritual. (2) Be authentic. (3) Know yourself. (4) Connect to the world. (5) Meditate. (6) Think positively. (7) Take control. (8) Live healthily. (9) Live simply. (10) Follow your gut feelings. Empirical research on happiness provides indirect support for most of these recommendations. Yet, this evidence falls short because some recommendations have not yet been studied, some advice might not be suitable for the specific New Age clientele, some advice might not be properly applied, and concrete practices might do more harm than good. We need well-controlled follow-up studies in order to settle the issue more definitively. 


\section{References}

Abdel-Khalek, A. M. (2003). Measuring happines by a single item scale. Working Paper, University of Kuwait.

Alloy, L. B., \& Abramson, L. Y. (1979). Judgment of contingency in depressed and non-depressed students: Sadder but wiser? Journal of Experimental Psychology, 108(4), 441-485.

Alexander, C. N., Rainforth, M. V., \& Gelderloos, P. (1991). Transcendental meditation, selfactualization, and psychological health: A conceptual overview and statistical meta-analysis. Journal of Social Behavior and Personality, 6(5), 189-248.

Argyle, M. (1996). In pursuit of the Quality of Life. Oxford University Press.

Aupers, S., \& Van Otterloo, A. (2000). New age: Een Godsdiensthistorische en sociologische benadering. Kampen: Uitgeverij Kok.

Beck, A. T. (1967). Depression: Clinical, experimental and theoretical aspects. New York: Hoeber.

Becker, J. W., Hart, J. de., \& Mens, J. (1997). Secularisatie en alternatieve zingeving in Nederland. Rijswijk: Sociaal en Cultureel Planbureau.

Belk, R. W. (1984). Three scales to measure constructs related to materialism: Reliability, validity, and relationships to measures of happiness. In T. C. Kinnear (Ed.), Advances in consumer research (Vol. 11, pp. 291-297), Provo, UT.

Brickman, P., Coates, D., \& Janoff-Bulman, R. (1978). The lottery winners and accident victims: Is happiness relative? Journal of Personality and Social Psychology, 36(8), 917-927.

Brief, A. P., Butcher, A. H., George, J. M., \& Link, K. E. (1993). Integrating bottom-up and top-down theories of subjective well-being: The case of health. Journal of Personality and Social Psychology, 64, 646-653.

Brown, B. W., \& Ryan, R. M. (2003). The benefits of being present: The role of mindfulness in psychological well-being. Journal of Personality and Social Psychology, 84, 822-848.

Chiriboga, D. A. (1982). Consistency in adult functioning: The influence of social stress. Aging and society, 2, 7-29.

Cox, R. H., Liu, Z., \& Qiu, Y. (1996). Psychological skills of elite Chinese athletes. International Journal of Sport Psychology, 27(2), 123-132.

Csikszentmihalyi, M. (1975). Beyond Boredom and Anxiety. San Fransisco: Jossy-Bass.

Csikszentmihalyi, M. (1990). Flow: The psychology of optimal experience. New York: Harper and Row.

Cummins, R. A., Eckersley, R., Lo, S. K., \& Okerstrom, E. (2003). The well being of australians: Impact of the impending Iraq war. Australian Centre on Quality of Life. Melbourne, Australia. Retrieved from http://acqol.deakin edu.au.

Diener, E. (1984). Subjective well-being. Psychological Bulletin, 95, 542-575.

Diener, E., Sandvik, E., Seidlitz, L., \& Diener, M. (1993). The relationship between income and subjective well-being: Relative or absolute? Social Indicators Research, 28(3), 195-223.

Dunning, D., Heath, C., \& Suls, J. (2004). Flawed self-assessment: Implications for health, education, and the workplace. Psychological Science in the Public Interest, 5, 69-106.

Ellis, A., \& Grieger, R. (1977). Handbook of rational-emotive therapy. New York: Springer Publishers \& Co.

Erbes J. T., \& Cunneen Henderson J. J. (1985). A longitudinal examination of the separation/divorce process. Journal of Marriage and the Family, 11, 937-941.

Feist, G. J., Bodner, T. E., Jacobs, J. F., Miles, M., \& Tan, V. (1995). Integrating top-down and bottom-up structural models of subjective well-being: a longitudinal investigation. Journal of Personality and Social Psychology, 68, 138-150.

Freud, S. (1969). An outline of psycho-analysis. London: Hogarth Press, Institute of Psycho-Analysis.

Gall, T. L. (2000). Integrating religious resources within a general model of stress and coping : Longterm adjustment to breast cancer. Journal of Religion and Health, 39, 167-182.

Goodhart, D. E. (1985). Some psychological effects associated with positive and negative thinking about stressful event outcomes: Was polyanna right? Journal of Personality and Social Psychology, 48, 216-232.

Greeley, A. M. (1975). The sociology of the paranormal. London: Sage.

Halman, L., Heunks, F., Moor, R. de., \& Zanders, H. (1987). Traditie, secularisatie en individualisering. Tilburg: Tilburg University Press.

Hanegraaff, W. (1996). New Age, religion and western culture: Esotericism in the mirror of secular thought. Leiden, New York/Köln: E. J. Brill.

Headey, B. (1981). The quality of life in Australia. Social Indicators Research, 9, 155-181. 
Headey, B., Kelley, J., \& Wearing, A. (1993). Dimensions of mental health: Life satisfaction, positive affect, anxiety and depression. Social Indicators Research, 29, 63-82.

Headey, B., \& Wearing, A. (1992). Understanding happiness. A theory of subjective wellbeing. Melbourne, Australia: Longman Cheshire.

Kaldor, P. (1994). Winds of change: the experience of church in a changing Australia. Homebush West, Lancer.

Larson, R. (1989). Is feeling “in control” related to happiness in daily life? Psychological Reports, 64, $777-784$.

Matlin, M. W., \& Gawron, V. J. (1979). Individual differences in pollyannaism. Journal of Personality Assessment, 43, 411-412.

Mirowsky, J., \& Ross, C. E. (1990). Control or defense? Depression and the sense of control over good and bad outcomes. Journal of Health and Social Behavior, 31, 71-86.

Moberg, D. O., \& Taves, M. J. (1965). Churchparticipation and adjustment in old age. In A. M. Rose, \& W. A. Peterson (Eds.), Older people and their social world (pp. 113-124). Philadelphia, USA: F.A. Davis Cie.

Myers, D. G., \& Diener, E. (1995). Who is happy? Psychological Science, 6(1), 10-19.

Nock, S. L. (1981). Family life-cycle transitions: Longitudinal effects on family members. Journal of Marriage and the Family, 43, 703-714.

Norem, J. K., \& Chang, E. C. (2002). The positive psychology of negative thinking. Journal of Clinical Psychology, 58(9), 993-1001.

Okun, M. A., \& George, L. K. (1984). Physician- and self-ratings of health, neuroticism and subjective wellbeing among men and women. Personality and Individual Differences, 5(5), 533-539.

Palmore, E. B. (1981). Social patterns in normal aging: Findings from the duke longitudinal study (pp. 95-107). Durham, North Carolina: Duke University Press.

Piliavin, J. A., \& Callero, P. L. (1991). Giving blood: the development of an altruistic identity. Baltimore: John Hopkins University Press.

Pollner, M. (1989). Divine relations, social relations and well-being. Journal of Health and Social Behavior, 30, 92-104.

Rilling, J., Gutman, D., Zeh, T., Pagnoni, G., Berns, G., \& Kilts, C. (2002). A neural basis for social cooperation. Neuron, 35(2), 395-405.

Ryff, C. D., \& Keyes, C. L. (1995). The structure of psychological well-being revisited. Journal of Personality and Social Psychology, 69, 719-727.

Seligman, M. E. P. (2002). Authentic happiness: Using the new positive psychology to realize your potential for lasting fulfillment. New York: Free Press.

Suchman, E. A., Phillips, B. S., \& Streib, G. F. (1958). An analysis of the validity of health questionnaires. Social Forces, 36, 223-232.

Taylor, S. E., \& Brown, J. D. (1988). Illusion and well-being: a social psychological perspective on mental health. Psychological Bulletin, 103(2), 193-210.

Timmermans, D. (1997). Correlates of happiness in 42 nations: Analysis of the worldvalues Study 1990-1991. Working paper, Department of Sociology, Erasmus University Rotterdam.

Veenhoven, R. (1984). Conditions of happiness. Dordrecht/Boston: D. Reidel. Reprinted in 1989 by Kluwer Academic, Dordrecht/Boston.

Veenhoven, R. (1994). Is happiness a trait? Tests of the theory that a better society does not make people any happier. Social Indicators Research, 32, 101-160.

Veenhoven, R. (1996). Happy life-expectancy. A comprehensive measure of quality-of-life in nations. Social Indicators Research, 39, 1-58.

Veenhoven, R. (1999). Quality of life in individualistic society: a comparison in 43 nations in the early 1990s. Social Indicators Research, 48, 157-186.

Veenhoven, R. (2001). Hedonism and happiness. In Proceedings of the 7th ARISE symposium the senses, pleasure and health 7-10 October, 2002 nice, France, associates for research into the science of enjoyment, London pp. 121-136.

Veenhoven, R. (2005a). World database of happiness, correlational findings: Erasmus university Rotterdam, Retrieved from: http://worlddatabaseofhappiness.eur.nl.

Veenhoven, R. (2005b). Gezond geluk (healthy happiness). Report for ZonMw: Dutch organization for health research and development, The Hague.

Weiss, R. F., Buchanan, W., Altstatt, L., \& Lombardo, J. P. (1971). Altruism is rewarding. Science, $171,1262-1263$.

Wessman, A. E., \& Ricks, D. F. (1966). Mood and personality. New York: Holt.

Witter, R. A., Okun, M. A., Haring-Hidore, M. J., \& Stock, W. A. (1985). Religion and subjective well-being in adulthood: A quantitative synthesis. Review of Religious Research, 26, 332-342. 


\section{Non-scientific references}

Ban Breathnach, S. (1995). Simple abundance (a daybook of comfort and joy). New York: Warner Books.

Blavatsky, H. P. (1950). The secret doctrine. London: Adyar.

Butler-Bowdon, T. (2005). 50 spiritual classics. Finland: WS Bookwell.

Castañeda, C. E. (1972). The teachings of Don Juan: A Yaqui way of knowledge. CA: University of California Press.

Chinmoy, S. (1979). Meditation: Man-perfection in God-satisfaciton. New York: Aum Publications. Chopra, D. (2001). How to know God. Philadelphia, PA: Miniature Editions.

Dass, R. (1971). Be here now, remember; Remember, be here. New York: The Lama Foundation.

Dyer, W. W. (1997). Manifest your destiny: The nine spiritual principles for getting everything you want. New York: Harper Collins.

Hay, L. L. (1984). You can heal your life. Carson: Hay House.

Krishnamurti, J. (1995). The book of life: Daily meditations. San Francisco: Harper.

Nhat Hanh, T. (1975). The miracle of mindfulness. Boston: Beacon Press.

Redfield, J. (1997). The celestine vision. Rockland, MA: Wheeler Publication.

Walsch, N. D. (1997). Conversations with God: Book 2. New York: Putnam's Sons. 